\title{
Analysis of the frequency of oncogenic driver mutations and correlation with clinicopathological characteristics in patients with lung adenocarcinoma from Northeastern Switzerland
}

\author{
Alexandra Grosse ${ }^{1}$, Claudia Grosse ${ }^{2 *}$, Markus Rechsteiner ${ }^{3}$ and Alex Soltermann ${ }^{1}$
}

\begin{abstract}
Background: Molecular testing of lung adenocarcinoma for oncogenic driver mutations has become standard in pathology practice. The aim of the study was to analyze the EGFR, KRAS, ALK, RET, ROS1, BRAF, ERBB2, MET and PIK3CA mutational status in a representative cohort of Swiss patients with lung adenocarcinoma and to correlate the mutational status with clinicopathological patient characteristics.

Methods: All patients who underwent molecular testing of newly diagnosed lung adenocarcinoma during a 4-year period (2014-2018) were included. Molecular analyses were performed with Sanger sequencing $(n=158)$ and next generation sequencing $(n=311)$. ALK, ROS1 and RET fusion gene analyses were also performed with fluorescence in situ hybridization and immunohistochemistry/immunocytochemistry. Demographic and clinical data were obtained from the medical records.

Results: Of 469 patients with informative EGFR mutation analyses, 90 (19.2\%) had EGFR mutations. KRAS mutations were present in $33.9 \%$ of the patients, while $6.0 \%$ of patients showed ALK rearrangement. BRAF, ERBB2, MET and PIK3CA mutations and ROS1 and RET rearrangements were found in 2.6\%, 1.9\%, 1.9\%, 1.5\%,1.7\% and $0.8 \%$ of the patients, respectively. EGFR mutation was significantly associated with female gender and never smoking status. ALK translocations were more frequent in never smokers, while KRAS mutations were more commonly found in ever smokers. The association between KRAS mutational status and female gender was statistically significant only on multivariate analysis after adjusting for smoking.

Conclusion: The EGFR mutation rate in the current study is among the higher previously reported mutation rates, while the frequencies of KRAS, BRAF, ERBB2 and PIKBCA mutations and ALK, ROS1 and RET rearrangements are similar to the results of previous reports. EGFR and KRAS mutations were significantly associated with gender and smoking. ALK rearrangements showed a significant association with smoking status alone.
\end{abstract}

Keywords: Lung adenocarcinoma, EGFR, KRAS, ALK, RET, ROS1, BRAF, ERBB2, MET, PIK3CA, Non-small cell lung cancer

\footnotetext{
* Correspondence: claudiagrosse@gmx.at

${ }^{2}$ Institute of Pathology, Kepler University Hospital, Krankenhausstraße 9, 4021

Linz, Austria

Full list of author information is available at the end of the article
}

(c) The Author(s). 2019 Open Access This article is distributed under the terms of the Creative Commons Attribution 4.0 International License (http://creativecommons.org/licenses/by/4.0/), which permits unrestricted use, distribution, and reproduction in any medium, provided you give appropriate credit to the original author(s) and the source, provide a link to the Creative Commons license, and indicate if changes were made. The Creative Commons Public Domain Dedication waiver (http://creativecommons.org/publicdomain/zero/1.0/) applies to the data made available in this article, unless otherwise stated. 


\section{Background}

Lung cancer is the leading cause of cancer-related mortality worldwide [1]. Non-small cell lung cancer (NSCLC) is the most common histological subtype of lung cancer, accounting for approximately $80-85 \%$ of lung cancer cases $[2,3]$. Molecular testing for epidermal growth factor receptor gene $(E G F R)$ mutations and ALK receptor tyrosine kinase $(A L K)$ translocations has become the evidencebased standard of care for the management of advanced NSCLC. In the past, pivotal clinical trials have demonstrated clinical benefit from targeting EGFR mutations and $A L K$ translocations, and currently a number of effective $E G F R$ and $A L K$ inhibitors are available for targeted therapy of NSCLC harboring the relevant aberrations [4]. More recently, new molecular profiling technologies have permitted the identification of other potential oncogenic drivers including mutations in the KRAS proto-oncogene (KRAS), B-Raf proto-oncogene $(B R A F)$, erb-b2 receptor tyrosine kinase 2 gene (ERBB2), MET proto-oncogene (MET) and phosphatidylinositol-3 kinase catalytic subunit alpha gene (PIK3CA) as well as ROS proto-oncogene 1 (ROS1) and ret proto-oncogene (RET) rearrangements [4]. While a number of studies have already evaluated the frequencies of these genetic alterations in NSCLC patients from different countries, information on the prevalence of oncogenic driver mutations in the Swiss population are scarce and limited to population based epidemiological data derived from cancer registries and molecular test results based exclusively on Sanger sequencing rather than next generation sequencing (NGS) [5, 6].

In Switzerland lung cancer is the most common cause of cancer-related death among men (approximately 2000 deaths per year) and the second most common cause of cancer-related death among women (approximately 1100 deaths per year) [7]. Adenocarcinoma is the predominant histological subtype with distinct molecular features, and incidence rates of lung adenocarcinoma are increasing among both sexes $[8,9]$. The aim of the study was to analyze the frequencies of $A L K, R E T$ and $R O S 1$ gene rearrangements and EGFR, KRAS, BRAF, ERBB2, MET and PIK3CA mutations in a representative cohort of Swiss patients with lung adenocarcinoma using NGS as testing method in the majority of cases and to correlate the molecular findings with clinicopathological patient characteristics.

\section{Methods}

\section{Patients}

A total of 475 consecutive patients who underwent molecular testing of newly diagnosed lung adenocarcinoma at the Institute of Pathology and Molecular Pathology, University Hospital Zurich (Zurich, Switzerland), between January 2014 and January 2018, were included in the study, independent of tumor stage. Molecular analyses were performed at the University Hospital Zurich according to National Comprehensive Cancer Network (NCCN) and Swiss Society of Pathology (SSPath) guidelines. Inclusion criteria were histologically and/or cytologically confirmed lung adenocarcinoma, chemotherapy, targeted therapy and radiotherapy naïve, and tissue blocks/cell blocks with adequate tumor cellularity. Exclusion criteria were non-adenocarcinoma histology, previous chemotherapy, targeted therapy or radiotherapy, and insufficient tumor material. Of the initial study population, 469 patients had adequate tumor material for molecular testing, while 6 patients had insufficient tumor samples and were not further evaluated. The results of molecular analysis were recorded for each patient and correlated with demographic and tumor related data such as gender, age, smoking status, clinical stage, and TNM stage (as defined by the Union for International Cancer Control (UICC) TNM classification of malignant tumors, 8th edition [10]). Smoking status was defined as never smokers ( $<100$ lifetime cigarettes), ex-smokers ( $\geq 100$ lifetime cigarettes and currently not smoking) and current smokers ( $\geq 100$ lifetime cigarettes and currently smoking). The cutoff date for data collection was 15 May 2018. The study was approved by the Cantonal Ethics Committee of Zurich (StV-No. 2009/14-0029).

\section{Molecular analysis}

Nucleic acids (DNA and RNA) were isolated from formalin-fixed paraffin-embedded (FFPE) tissue blocks or FFPE cell blocks using the Maxwell 16 FFPE Tissue LEV DNA/RNA Purification Kit (Promega, Fitchburg, WI, USA). The obtained nucleic acids were quantified with NanoDrop ND-1000 spectrophotometer (Thermo Fisher Scientific, Wilmington, DE, USA) and Qubit 2.0 (Thermo Fisher Scientific/Life Technologies, Eugene, OR, USA) using the dsDNA/RNA HS Assay Kit (Thermo Fisher Scientific/Life Technologies, Zug, Switzerland). Mutation analysis was performed using Sanger sequencing $(n=158)$ or NGS $(n=311)$. For DNA- and RNA-based NGS, customer panels including the Ion AmpliSeq Colon and Lung Cancer panel 2 (CLP2), Ion AmpliSeq Fusion Lung Cancer Research panel (LFP), and Oncomine DNA panel for Solid Tumors and Fusion Transcripts (Thermo Fisher Scientific/Life Technologies, Carlsbad, California, USA) were applied, as previously described [11, 12]. Briefly, we used the Ion Library Quantitation kit (Thermo Fisher Scientific) for quantification of DNA and RNA libraries, the Ion One Touch 200 Template Kit v2 DL (lately replaced by the Ion $\mathrm{Hi}$-Q Chef Kit and the Ion Chef System) (Thermo Fisher Scientific) for emulsion polymerase chain reaction (PCR) and template preparation, and the Ion Personal Genome Machine 200 Kit v2 (lately replaced by the Ion Personal Genome Machine Hi-Q Sequencing Kit) (Thermo Fisher Scientific) as the 
sequencing platform. For Sanger sequencing, we used the Illustra GFX PCR DNA and Gel Band Purification Kit (GE Healthcare Life Sciences, Buckinghamshire, UK) for purification of amplified DNA fragments, the Genetic Analyzer $3130 \times 1$ (Applied Biosystems, Foster City, CA, USA) for sequencing and the Sequencher 5.1 (Gene Code Corporation, Ann Arbor, MI, USA) for data analysis. $A L K$ and ROS1 immunohistochemistry (IHC)/immunocytochemistry (ICC) was performed on the automated immunostainer DiscoveryUltra (Roche Ventana) using a mouse anti-human $A L K$ monoclonal antibody (clone 5A4, Leica Biosystems) and a rabbit anti-human ROS1 monoclonal antibody (clone D4D6, Cell Signaling Technology). ALK or ROS1 IHC/ICC positive cases were confirmed by fluorescence in situ hybridization (FISH) using the Vysis LSI ALK Dual Color Break Apart Rearrangement Probe (Abbott Molecular, Baar, Switzerland) and the ZytoLight SPEC ROS1 Dual Color Break Apart Probe (Zytovision GmbH, Bremerhaven, Germany). FISH testing for RET rearrangement was performed using the ZytoLight SPEC RET Dual Break Apart Probe (Zytovision GmbH, Bremerhaven,
Germany). For each case, a board certified pathologist analyzed 50-100 tumor nuclei. A sample was considered positive, if split signals were detected in $\geq 15 \%$ of tumor nuclei according to the manufacturer's evaluation guidelines (Abbott Molecular, Des Plaines, IL, USA).

\section{Statistical analysis}

Descriptive statistics were employed to describe the patient characteristics of the study cohort. The results are presented as frequencies and percentages for categorical variables and as mean \pm standard deviation, median and range for continuous variables. Associations between mutation status and clinicopathological characteristics were tested using univariate and multivariate analyses. Univariate analysis was performed by chi-square test or Fisher exact test for categorical variables and by $t$ test or nonparametric Mann-Whitney test for continuous variables. Multivariate analysis was performed by logistic regression. $P$-values $<0.05$ were considered statistically significant. All statistical analyses were performed using SPSS Statistics software (version 24.0, IBM, Ehningen, Germany).

Table 1 Patient characteristics

\begin{tabular}{|c|c|c|c|}
\hline Variable & $\begin{array}{l}\text { Study population } \\
(n=469)\end{array}$ & Variable & $\begin{array}{l}\text { Study population } \\
(n=469)\end{array}$ \\
\hline Age (years) & $64.1 \pm 11.4$ & $\mathrm{~N}$ stage & \\
\hline Gender & & No & $117(24.9)$ \\
\hline Male & $235(50.1)$ & N1 & 65 (13.9) \\
\hline Female & $234(49.9)$ & N2 & $134(28.6)$ \\
\hline Smoking status & & N3 & $153(32.6)$ \\
\hline Never smokers & $115(24.5)$ & Extrathoracic metastasis/-es & $213(45.4)$ \\
\hline Ex-smokers & $160(34.1)$ & M stage & \\
\hline Current smokers & $194(41.4)$ & Mo & $168(35.8)$ \\
\hline Clinical stage & & M1a & $88(18.8)$ \\
\hline । & $34(7.2)$ & M1b & $72(15.4)$ \\
\hline$\|$ & $36(7.7)$ & M1c & $141(30.1)$ \\
\hline III & $100(21.3)$ & Localization & \\
\hline IV & $299(63.8)$ & Right upper lobe & $121(25.8)$ \\
\hline T stage & & Right lower lobe & 65 (13.9) \\
\hline $\mathrm{T} 1$ & $68(14.5)$ & Middle lobe & $19(4.1)$ \\
\hline T1a & $9(1.9)$ & Left upper lobe & $88(18.8)$ \\
\hline$T 1 b$ & $28(6.0)$ & Left lower lobe & $73(15.6)$ \\
\hline T1c & $31(6.6)$ & Lingula & $14(3.0)$ \\
\hline $\mathrm{T} 2$ & $120(25.6)$ & Involvement of two lobes & 89 (19.0) \\
\hline $\mathrm{T} 2 \mathrm{a}$ & $81(17.3)$ & Distribution & \\
\hline $\mathrm{T} 2 \mathrm{~b}$ & $39(8.3)$ & Central & $96(20.5)$ \\
\hline T3 & $93(19.8)$ & Peripheral & $323(68.9)$ \\
\hline T4 & $188(40.1)$ & Central and peripheral & $50(10.7)$ \\
\hline Lymph node metastasis/-es & $352(75.1)$ & Size $(\mathrm{mm})$ & $45 \pm 25$ \\
\hline
\end{tabular}

Data are mean values \pm standard deviations for continuous variables and number of patients with percentages in parentheses for categorical variables 
Table 2 EGFR mutations in 90 lung cancers

\begin{tabular}{|c|c|c|c|c|}
\hline & cDNA change & Amino acid change & Frequency & Percentage \\
\hline Exon 21 & c. $2573 \mathrm{~T}>\mathrm{G}$ & p.L858R & 35 & 38.9 \\
\hline Exon 19 & c.2235_2249del/c.2236_2250del ${ }^{a}$ & p.E746_A750del & 33 & 36.7 \\
\hline Exon 19 & c.2240_2257del & p.L747_P753delinsS & 6 & 6.7 \\
\hline Exon 19 & c.2254_2277del & p.S752_1759del & 3 & 3.3 \\
\hline Exon 19 & c.2239_2253del & p.L747_T751del & 2 & 2.2 \\
\hline Exon 19 & c.2239_2248delinsC & p.L747_A750delinsP & 2 & 2.2 \\
\hline Exon 19 & c.2238_2252delinsGCA & p.L747_T751delinsQ & 1 & 1.1 \\
\hline Exon 19 & c.2239_2256del & p.L747_S752del & 1 & 1.1 \\
\hline Exon 19 & c.2237_2255delinsT & p.E746_S752delinsV & 1 & 1.1 \\
\hline Exon 18 & c. $2126 \mathrm{~A}>\mathrm{C}$ & p.E709A & 2 & 2.2 \\
\hline Exon 18 & c. $2126 A>G$ & p.E709G & 1 & 1.1 \\
\hline Exon 18 & c. $2156 G>C$ & p.G719A & 1 & 1.1 \\
\hline Exon 18 & c. $2155 G>T$ & p.G719C & 1 & 1.1 \\
\hline Exon 20 & c. $2303 G>T$ & p.S768l & 2 & 2.2 \\
\hline Exon 20 & c. $2320 \mathrm{G}>\mathrm{A}$ & p.V774 M & 1 & 1.1 \\
\hline Exon 21 & c. $2497 \mathrm{~T}>\mathrm{G}$ & p.L833 V & 1 & 1.1 \\
\hline Exon 21 & c. $2560 A>G$ & p.T854A & 1 & 1.1 \\
\hline
\end{tabular}

${ }^{\mathrm{a}}$ c.2235 2249del: $n=25 ;$ c.2236 2250del: $n=8$

\section{Results}

The diagnosis of lung adenocarcinoma was based on histology (with or without cytology) in 91.7\% (430/469) and on cytology alone in $8.3 \%(39 / 469)$ of the patients. Samples submitted for molecular testing were obtained from primary tumors, lymph node metastases or distant metastases in $79.7 \%(374 / 469), 10.7 \%(50 / 469)$ and $9.6 \%(45 /$ 469) of the patients, respectively. There were 191 (40.7\%) resection specimens, 224 (47.8\%) biopsy specimens, 48 (10.2\%) fine needle aspiration/bronchial brushing/bronchoalveolar lavage specimens and $6(1.3 \%)$ cell blocks from pleural effusions. Table 1 summarizes the demographic and clinicopathological patient characteristics. The study population consisted of 235 men and 234 women (mean age at diagnosis, $64.1 \pm 11.4$ years; range, 27-94 years). The majority of patients were ever smokers (current smokers and ex-smokers) (354/469, 75.5\%) and had clinical stage IV lung adenocarcinoma (299/469, $63.8 \%)$ at diagnosis. Females were more likely to be never smokers than males $(70 / 234,29.9 \%$ vs $45 / 235,19.1 \%, p=$ 0.007 , beta 0.589 , OR 1.802 , CI 95\% 1.174-2.767). Overall 127 patients received targeted treatment. Stage IV patients (both at diagnosis and during follow-up) with EGFR mutation and $A L K$ rearrangement received targeted treatment in $75.4 \%$ and $61.9 \%$, respectively. The majority $(91.7 \%)$ of stage IV patients with EGFR mutation who did not receive targeted therapy were treated with chemotherapy and/or radiotherapy. Likewise, all stage IV patients with $A L K$ translocation who were not treated with targeted therapy received chemotherapy and/or radiotherapy. Median patient follow-up was 17 months (range, 1-52 months). $268 / 469$ (57.1\%) patients were alive at the time of last follow-up, including 165/469 (35.2\%) patients with stable disease and 103/469 (22.0\%) patients with progressive disease. 147/469 (31.3\%) patients died of disease during follow-up, and $54 / 469$ (11.5\%) patients were lost to follow-up. Median overall survival for the entire study cohort was 38 months.

\section{EGFR mutation analysis}

A total of 95 EGFR mutations were detected in $90 / 469$ (19.2\%) patients. The most common EGFR mutations were exon 19 deletions (49/90, 54.4\%, most frequent subtype: E746_A750del, 33/90, 36.7\%) and exon 21 L858R missense mutations (35/90, 38.9\%) (Table 2). Doublet EGFR mutations were found in $5(5 / 90,5.6 \%)$ tumors, including 2 tumors with L858R and non-L858R missense mutations, 2 tumors with two non-L858R missense mutations and 1 tumor with non-L858R missense mutation and T854A primary resistant mutation (Additional file 1: Table S1). The analysis of the distribution of EGFR mutations among men and women showed a predominance of EGFR mutations in the female group: 55/234 (23.5\%) women had a total of 59 EGFR mutations (most frequent: exon 19 deletion, 31/ $55,56.4 \%)$. By contrast, 35/235 (14.9\%) males had a total of 36 EGFR mutations, the most common of which - as in the female group - were exon 19 deletions $(18 / 35,51.4 \%)$. The highest prevalence of EGFR mutations was observed in never smokers $(69 / 115,60.0 \%)$ and was considerably lower in ex-smokers $(10 / 160,6.3 \%)$ and current smokers 
Table 3 Associations between clinicopathological features and EGFR mutational status

\begin{tabular}{|c|c|c|c|}
\hline Variable & $\begin{array}{l}\text { EGFR wt } \\
(n=379)\end{array}$ & $\begin{array}{l}\text { EGFR } \mathrm{mt} \\
(n=90)\end{array}$ & $p$-value \\
\hline Age (years) & $64.1 \pm 10.9$ & $64.2 \pm 13.1$ & 0.946 \\
\hline Gender & & & 0.020 \\
\hline Male & $200(52.8)$ & $35(38.9)$ & \\
\hline Female & $179(47.2)$ & $55(61.1)$ & \\
\hline \multicolumn{4}{|l|}{ Smoking status } \\
\hline Never smokers & $46(12.1)$ & $69(76.7)$ & $<0.001$ \\
\hline Ex-smokers & $150(39.6)$ & $10(11.1)$ & $<0.001$ \\
\hline Current smokers & $183(48.3)$ & $11(12.2)$ & $<0.001$ \\
\hline \multicolumn{4}{|l|}{ Clinical stage } \\
\hline । & $25(6.6)$ & $9(10.0)$ & 0.263 \\
\hline$\|$ & $32(8.4)$ & $4(4.4)$ & 0.200 \\
\hline$\|$ & $88(23.2)$ & $12(13.3)$ & 0.040 \\
\hline IV & $234(61.7)$ & $65(72.2)$ & 0.063 \\
\hline \multicolumn{4}{|l|}{ T stage } \\
\hline $\mathrm{T} 1$ & $55(14.5)$ & $13(14.4)$ & 0.987 \\
\hline T1a & $7(1.8)$ & $2(2.2)$ & 0.685 \\
\hline $\mathrm{T} 1 \mathrm{~b}$ & $26(6.9)$ & $2(2.2)$ & 0.095 \\
\hline T1c & $22(5.8)$ & $9(10.0)$ & 0.150 \\
\hline $\mathrm{T} 2$ & $90(23.7)$ & 30 (33.3) & 0.061 \\
\hline T2a & $55(14.5)$ & $26(28.9)$ & 0.001 \\
\hline $\mathrm{T} 2 \mathrm{~b}$ & $35(9.2)$ & $4(4.4)$ & 0.139 \\
\hline T3 & 77 (20.3) & $16(17.8)$ & 0.587 \\
\hline T4 & $157(41.4)$ & $31(34.4)$ & 0.224 \\
\hline LN metastasis/-es & $289(76.3)$ & $63(70.0)$ & 0.218 \\
\hline \multicolumn{4}{|l|}{ N stage } \\
\hline NO & $90(23.7)$ & $27(30.0)$ & 0.218 \\
\hline N1 & $57(15.0)$ & $8(8.9)$ & 0.129 \\
\hline N2 & $114(30.1)$ & $20(22.2)$ & 0.138 \\
\hline N3 & $118(31.1)$ & 35 (38.9) & 0.158 \\
\hline $\begin{array}{l}\text { Extrathoracic } \\
\text { metastasis-/es }\end{array}$ & $164(43.3)$ & $49(54.4)$ & 0.056 \\
\hline \multicolumn{4}{|l|}{ M stage } \\
\hline MO & $143(37.7)$ & $25(27.8)$ & 0.077 \\
\hline M1a & $72(19.0)$ & $16(17.8)$ & 0.790 \\
\hline $\mathrm{M} 1 \mathrm{~b}$ & $60(15.8)$ & $12(13.3)$ & 0.555 \\
\hline M1c & $104(27.4)$ & $37(41.1)$ & 0.011 \\
\hline \multicolumn{4}{|l|}{ Localization } \\
\hline Right upper lobe & $95(25.1)$ & $26(28.9)$ & 0.456 \\
\hline Right lower lobe & $57(15.0)$ & $8(8.9)$ & 0.129 \\
\hline Middle lobe & $15(4.0)$ & $4(4.4)$ & 0.770 \\
\hline Left upper lobe & $72(19.0)$ & $16(17.8)$ & 0.790 \\
\hline Left lower lobe & $60(18.8)$ & $13(14.4)$ & 0.744 \\
\hline Lingula & $13(3.4)$ & $1(1.1)$ & 0.487 \\
\hline
\end{tabular}

Table 3 Associations between clinicopathological features and EGFR mutational status (Continued)

\begin{tabular}{llll}
\hline Variable & $\begin{array}{l}\text { EGFR wt } \\
(n=379)\end{array}$ & $\begin{array}{l}\text { EGFR mt } \\
(n=90)\end{array}$ & $p$-value \\
\hline $\begin{array}{l}\text { Involvement of two lobes } \\
\text { Distribution }\end{array}$ & $67(17.7)$ & $22(24.4)$ & 0.141 \\
$\quad$ Central & $74(19.5)$ & $22(24.4)$ & 0.298 \\
Peripheral & $267(70.4)$ & $56(62.2)$ & 0.130 \\
$\quad$ Central and peripheral & $38(10.0)$ & $12(13.3)$ & 0.361 \\
Size $(\mathrm{mm})$ & $45.5 \pm 26.3$ & $44.7 \pm 20.3$ & 0.744
\end{tabular}

Data are mean values \pm standard deviations for continuous variables and number of patients with percentages in parentheses for categorical variables Bold numbers indicate significant $p$-values $(<0.05)$

(11/194, 5.7\%). The association between EGFR mutational status and either gender or smoking status was statistically significant on univariate $(p=0.019$ and $p<0.001$, respectively) and multivariate analyses $(p=0.033$ and $p<0.001$, respectively) (Tables 3 and 4). No statistically significant differences were found between EGFR mutated and EGFR wildtype tumors with respect to clinical stage (except for stage III, $p=0.040$ ), T stage (except for T2a, $p=0.001$ ), $\mathrm{N}$ stage, $\mathrm{M}$ stage (except for M1c, $p=0.011$ ), tumor location, mean tumor size and mean patient age (Table 3 ).

\section{KRAS mutation analysis}

Of 443 patients with informative KRAS mutation analysis, 159 (35.9\%) harbored KRAS mutations. KRAS mutations were most frequently located in exon $2(154 / 159,96.9 \%)$, and the most common mutations were G12C (72/159, $45.3 \%)$ and G12 V (26/159, 16.4\%) (Table 5). Of 443 patients with informative KRAS and EGFR mutation analyses, 2 patients (0.5\%) had coexistent KRAS and EGFR mutations (one with G13S and E746_A750del and one with G12 V and E709A). KRAS mutations tended to be more frequent in females $(86 / 217,39.6 \%)$ than in males $(73 / 226$, $32.3 \%)$ and were more commonly found in ever smokers $(152 / 353,43.1 \%)$ than in never smokers $(7 / 90,7.8 \%)$. The association between KRAS mutation and smoking status was statistically significant on both univariate and multivariate analyses after stratification by gender $(p<0.001$ and $p<0.001$, beta -2.285 , OR 0.102, CI 95\% 0.045-0.228), while gender was significantly associated with KRAS mutation only on multivariate analysis after adjusting for smoking ( $p=0.016$, beta 0.507 , OR 1.660 , CI 95\% 1.099-2.507) (Tables 6 and 7). Among the patients with informative KRAS mutation analysis, males were significantly more likely to be ever smokers (current smokers or ex-smokers) than females $(190 / 226,84.1 \%$ vs $163 / 217,75.1 \%, p=0.020$, beta 0.559 , OR 1.748 , CI $95 \% 1.092-2.800$ ). No statistically significant differences were found between KRAS mutated and KRAS wildtype tumors with respect to clinical stage, $\mathrm{T}$ stage (except for T2, $p=0.043$ ), $\mathrm{N}$ stage, $\mathrm{M}$ stage, tumor 
Table 4 Logistic regression analysis of EGFR mutational status

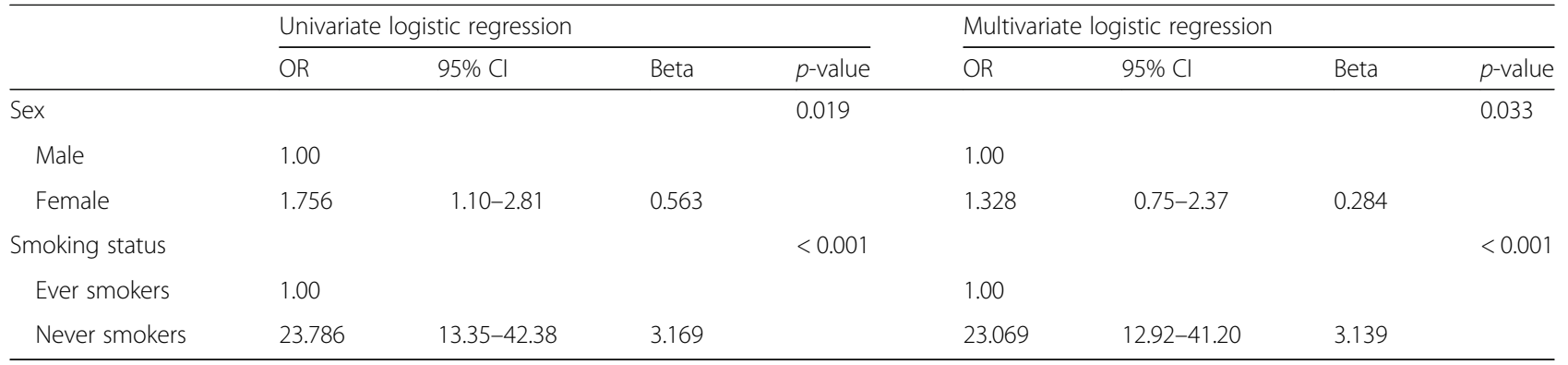

location (except for the left lower lobe, $p=0.006$ ), mean tumor size and mean patient age (Table 6).

\section{ALK rearrangement analysis}

$A L K$ rearrangement was detected by FISH $(n=20)$ or NGS $(n=8)$ in $28 / 376(7.4 \%)$ tumors, including one with coexistent KRAS mutation (G12 V). Of the 8 cases with ALK rearrangement diagnosed by NGS, EML4 exon 13-ALK exon 20 fusion gene variant was found in 4 (50.0\%) cases, EML4 exon 6- $A L K$ exon 20 fusion gene variant was detected in 3 (37.5\%) cases, and EML4 exon 18-ALK exon 20 fusion gene variant was detected in 1 (12.5\%) case. There was no significant difference in the frequency of $A L K$ rearrangement between males and females $(15 / 198,7.6 \%$ vs $13 / 178,7.3 \%$, univariate analysis, $p=0.920$, multivariate logistic regression, $p=0.669$ ) (Tables 8 and 9). By contrast, $A L K$ rearrangement was significantly more common in never smokers than in ever smokers $(12 / 84,14.3 \%$ vs $16 / 292$, $5.5 \%, p=0.007$ ) (Table 8). The association between $A L K$ rearrangement and smoking status remained statistically significant on multivariate analysis after adjusting for gender ( $p=0.008$, beta 1.081, OR 2.948, CI 95\% 1.323-6.567) (Table 9). Among the patients tested for $A L K$ rearrangement, females were more likely to be never smokers than males $(49 / 178,27.5 \%$ vs $35 / 198,17.7 \%, p=$ 0.023 , beta 0.570 , OR 1.769 , CI 95\% 1.082-2.892). No statistically significant differences were found between $A L K$-rearranged and $A L K$ wildtype tumors with respect to clinical stage (except for stage III, $p=0.038$ ), T stage (except for T1b, $p=0.025)$, $\mathrm{N}$ stage (except for $\mathrm{N} 2, p=0.003$ ), $M$ stage (except for M1b, $p=0.013$ ), tumor location (except for the right upper lobe, $p=0.001$, and the middle lobe, $p=0.019$ ), mean tumor size and mean patient age (Table 8 ).

$K R A S$ mutation analysis was not performed in 26 patients with proven EGFR mutation, and $A L K$ rearrangement testing was not performed in 93 patients including 62 patients with KRAS mutation and 31 patients with EGFR mutation. Because genetic alterations in EGFR, KRAS and $A L K$ are generally mutually exclusive, it can be concluded that $90 /$ 469 (19.2\%) patients had EGFR mutations, 159/469 (33.9\%) had KRAS mutations, and 28/469 (6.0\%) had ALK gene rearrangement (Table 10). 195/469 (41.6\%) patients had triple-negative (EGFR-negative/KRAS-negative/ALKnegative) lung adenocarcinomas.

Table 5 KRAS mutations in 159 lung cancers

\begin{tabular}{|c|c|c|c|c|}
\hline & cDNA change & Amino acid change & Frequency & Percentage \\
\hline Codon 12/Exon 2 & c.34G > T & p.G12C & 72 & 45.3 \\
\hline Codon 12/Exon 2 & c.35G $>\mathrm{T}$ & p.G12V & 26 & 16.4 \\
\hline Codon 12/Exon 2 & c. $35 \mathrm{G}>\mathrm{A}$ & p.G12D & 20 & 12.6 \\
\hline Codon 12/Exon 2 & c. $35 \mathrm{G}>\mathrm{C}$ & p.G12A & 15 & 9.4 \\
\hline Codon 12/Exon 2 & c.34_35del & p.G12F & 3 & 1.9 \\
\hline Codon 12/Exon 2 & c.34G > C & p.G12R & 2 & 1.3 \\
\hline Codon 12/Exon 2 & c.34G > A & p.G12S & 1 & 0.6 \\
\hline Codon 13/Exon 2 & $c .37 G>T$ & p.G13C & 10 & 6.3 \\
\hline Codon 13/Exon 2 & $c .37 \mathrm{G}>\mathrm{A}$ & p.G13S & 2 & 1.3 \\
\hline Codon 13/Exon 2 & c. $38 \mathrm{G}>\mathrm{A}$ & p.G13D & 2 & 1.3 \\
\hline Codon 13/Exon 2 & c. $37 \mathrm{G}>\mathrm{C}$ & p.G13R & 1 & 0.6 \\
\hline Codon 61/Exon 3 & C. $183 \mathrm{~A}>\mathrm{C}$ & p.Q61H & 3 & 1.9 \\
\hline Codon 61/Exon 3 & c. $182 \mathrm{~A}>\mathrm{T}$ & p.Q61L & 2 & 1.3 \\
\hline
\end{tabular}


Table 6 Associations between clinicopathological features and KRAS mutational status

\begin{tabular}{|c|c|c|c|}
\hline Variable & $\begin{array}{l}\text { KRAS wt } \\
(n=284)\end{array}$ & $\begin{array}{l}\text { KRAS mt } \\
(n=159)\end{array}$ & $p$-value \\
\hline Age (years) & $64.7 \pm 12.0$ & $63.3 \pm 9.4$ & 0.193 \\
\hline Gender & & & 0.108 \\
\hline Male & $153(53.9)$ & $73(45.9)$ & \\
\hline Female & $131(46.1)$ & $86(54.1)$ & \\
\hline \multicolumn{4}{|l|}{ Smoking status } \\
\hline Never smokers & $83(29.2)$ & $7(4.4)$ & $<0.001$ \\
\hline Ex-smokers & 99 (34.9) & $61(38.4)$ & 0.461 \\
\hline Current smokers & $102(35.9)$ & $91(57.2)$ & $<0.001$ \\
\hline \multicolumn{4}{|l|}{ Clinical stage } \\
\hline । & $19(6.7)$ & $11(6.9)$ & 0.927 \\
\hline$\|$ & $24(8.5)$ & $10(6.3)$ & 0.412 \\
\hline III & $60(21.1)$ & $38(23.9)$ & 0.500 \\
\hline IV & $181(63.7)$ & $100(62.9)$ & 0.860 \\
\hline \multicolumn{4}{|l|}{ T stage } \\
\hline $\mathrm{T} 1$ & $39(13.7)$ & $26(16.4)$ & 0.455 \\
\hline T1a & $7(2.5)$ & $2(1.3)$ & 0.499 \\
\hline $\mathrm{T} 1 \mathrm{~b}$ & $16(5.6)$ & $11(6.9)$ & 0.588 \\
\hline T1c & $16(5.6)$ & $13(8.2)$ & 0.299 \\
\hline $\mathrm{T} 2$ & $78(27.5)$ & $30(18.9)$ & 0.043 \\
\hline T2a & $51(18.0)$ & $18(11.3)$ & 0.065 \\
\hline $\mathrm{T} 2 \mathrm{~b}$ & $27(9.5)$ & $12(7.5)$ & 0.485 \\
\hline T3 & $52(18.3)$ & $37(23.3)$ & 0.211 \\
\hline T4 & $115(40.5)$ & $66(41.5)$ & 0.835 \\
\hline LN metastasis/-es & $212(74.6)$ & $121(76.1)$ & 0.734 \\
\hline \multicolumn{4}{|l|}{ N stage } \\
\hline NO & $72(25.4)$ & $38(23.9)$ & 0.734 \\
\hline N1 & $33(11.6)$ & $27(17.0)$ & 0.114 \\
\hline N2 & $82(28.9)$ & $48(30.2)$ & 0.771 \\
\hline N3 & $97(34.2)$ & 46 (28.9) & 0.259 \\
\hline $\begin{array}{l}\text { Extrathoracic } \\
\text { metastasis/-es }\end{array}$ & $124(43.7)$ & $74(46.5)$ & 0.559 \\
\hline \multicolumn{4}{|l|}{ M stage } \\
\hline MO & 101 (35.6) & $59(37.1)$ & 0.746 \\
\hline M1a & $59(20.8)$ & $26(16.4)$ & 0.257 \\
\hline $\mathrm{M} 1 \mathrm{~b}$ & $37(13.0)$ & $30(18.9)$ & 0.100 \\
\hline M1c & 87 (30.6) & $44(27.7)$ & 0.512 \\
\hline \multicolumn{4}{|l|}{ Localization } \\
\hline Right upper lobe & $71(25.0)$ & $44(27.7)$ & 0.538 \\
\hline Right lower lobe & 45 (15.8) & $17(10.7)$ & 0.134 \\
\hline Middle lobe & $11(3.9)$ & $6(3.8)$ & 0.958 \\
\hline Left upper lobe & $52(18.3)$ & 31 (19.5) & 0.759 \\
\hline Left lower lobe & 33 (11.6) & $34(21.4)$ & 0.006 \\
\hline Lingula & $11(3.9)$ & $3(1.9)$ & 0.252 \\
\hline
\end{tabular}

Table 6 Associations between clinicopathological features and KRAS mutational status (Continued)

\begin{tabular}{|c|c|c|c|}
\hline Variable & $\begin{array}{l}\text { KRAS wt } \\
(n=284)\end{array}$ & $\begin{array}{l}\text { KRAS mt } \\
(n=159) \\
\end{array}$ & $p$-value \\
\hline Involvement of two lobes & $61(21.5)$ & $24(15.1)$ & 0.102 \\
\hline \multicolumn{4}{|l|}{ Distribution } \\
\hline Central & $64(22.5)$ & $27(17.0)$ & 0.165 \\
\hline Peripheral & $189(66.5)$ & $117(73.6)$ & 0.124 \\
\hline Central and peripheral & $31(10.9)$ & $15(9.4)$ & 0.624 \\
\hline Size (mm) & $45.8 \pm 25.8$ & $45.6 \pm 25.8$ & 0.937 \\
\hline
\end{tabular}

Data are mean values \pm standard deviations for continuous variables and number of patients with percentages in parentheses for categorical variables Bold numbers indicate significant $p$-values $(<0.05)$

\section{EGFR, KRAS and ALK comparative analyses}

Comparative analyses of EGFR and KRAS mutated tumors, EGFR mutated and $A L K$ rearranged tumors and KRAS mutated and $A L K$ rearranged tumors are summarized in Additional file 1: Tables S2-S4. Of note, EGFR mutated tumors were more likely to have multiple extrathoracic metastases (M1c) compared with KRAS mutated tumors (37/ 90, 41.1\% vs 44/159, 27.7\%, $p=0.030$ ) (Additional file 1: Table S2). EGFR mutated tumors were also more likely to be clinical stage IV and have single or multiple extrathoracic metastases (M1b or M1c) compared with $A L K$ rearranged tumors $(65 / 90,72.2 \%$ vs $14 / 28,50.0 \%, p=0.029$ and $49 / 90,54.4 \%$ vs $7 / 28,25.0 \%, p=0.006$ ) (Additional file 1: Table S3). ALK rearranged tumors were more frequently associated with clinical stage III than EGFR mutated tumors $(10 / 28,35.7 \%$ vs $12 / 90,13.3 \%, p=0.008)$ and more commonly showed ipsilateral mediastinal or subcarinal lymph node metastasis (N2) compared with EGFR and KRAS mutated lung adenocarcinomas $(15 / 28,53.6 \%$ vs $20 / 90,22.2 \%, p=0.002$ and $15 / 28,53.6 \%$ vs $48 / 159,30.2 \%$, $p=0.016)$.

\section{Other mutations and rearrangements}

RET fusions were detected by FISH in 4 (1.9\%) of 208 tested patients, including 1 patient with coexistent PIK3CA mutation (E545K). ROS1 fusions were detected by FISH $(n=5)$ or NGS $(n=3)$ in $8(3.2 \%)$ of 248 tested patients. No statistically significant differences were found between RET/ROS1 rearranged and non-rearranged tumors with respect to gender, smoking status, clinical stage, TNM stage, tumor location, mean tumor size and mean patient age. 12/309 (3.9\%) tumors harbored BRAF mutations. The majority of $B R A F$ mutations were located in exon 15 (10/12, 83.3\%); the most common BRAF mutation was V600E (9/12, 75.0\%) (Table 11). No statistically significant differences were found between $B R A F$ mutated and $B R A F$ wildtype tumors with respect to the clinicopathological parameters evaluated. ERBB2 mutations were detected in 9/286 (3.1\%) tumors (Table 12), including 7 insertion/duplication mutations in exon 20, 1 nonsense 
Table 7 Logistic regression analysis of KRAS mutational status

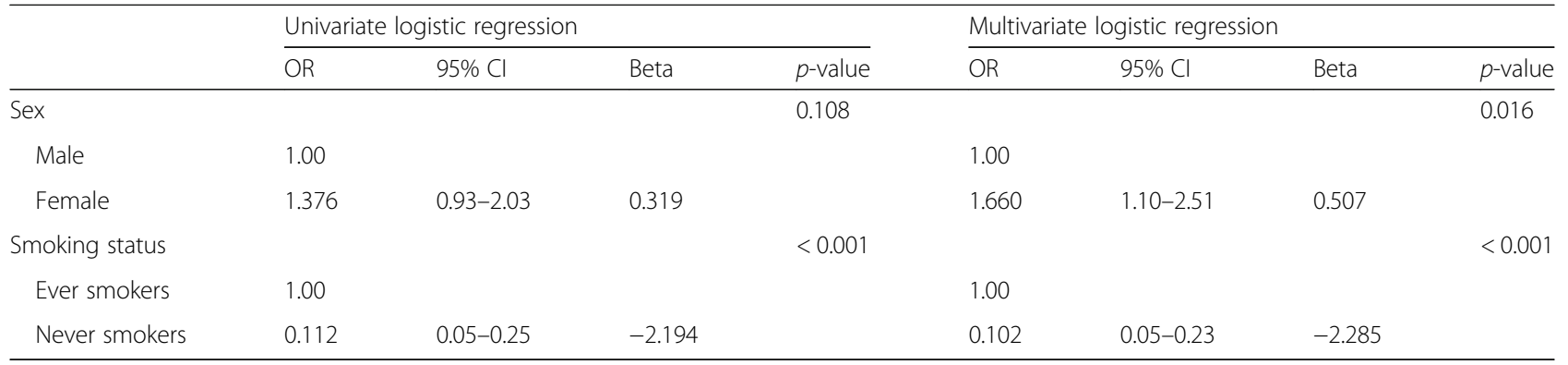

mutation in exon 13 and 1 missense mutation in exon 8 of the $E R B B 2$ gene; the most frequent $E R B B 2$ mutation was p.A775_G776insYVMA (alternative nomenclature p.Y772_A775dup, c.2313_2324dup) (5/9, 55.6\%). ERBB2 mutations were more common in never smokers than in ex-/current smokers $(5 / 64,7.8 \%$ vs $4 / 222,1.8 \%$, chi-square test, $p=0.029$, multivariate logistic regression, $p=0.020$, beta 1.621, OR 5.059, CI 95\% 1.296-19.747), while no significant differences were found between $E R B B 2$ mutated and ERBB2 wildtype tumors with respect to the other clinicopathological parameters analyzed. Nine $M E T$ exon 14 skipping mutations were detected in 234 (3.8\%) tumors, including one with coexistent $B R A F$ (V600E) and PIK3CA (E542K) mutation and one with coexistent KRAS (G13C) mutation. PIK3CA mutations were detected in 7/163 (4.3\%) tumors (3 x E542K, 2 x E545K, 1 $\mathrm{x}$ R38H, 1 x H1047R), including one with coexistent $B R A F$ (V600E) and MET exon 14 skipping mutation, two with coexistent EGFR mutations (L858R and L747_P753delinsS, respectively), one with coexistent KRAS (G12A) mutation and one with coexistent RET rearrangement. No statistically significant differences were found between $M E T / P I K 3 C A$ mutated and MET/PIK3CA wildtype tumors with respect to gender, smoking status, clinical stage, TNM stage, mean tumor size and mean patient age. While $M E T$ mutated tumors were more likely to be located in the right upper lobe than $M E T$ wildtype tumors (6/9, $66.7 \%$ vs $50 / 225,22.2 \%, p=0.007)$, PIK3CA mutated tumors were less likely peripheral in location and involved more frequently both the central and peripheral portions of the lung compared with PIK3CA wildtype tumors $(2 / 7$, $28.6 \%$ vs $107 / 156,68.6 \%, p=0.041$ and $3 / 7,42.9 \%$ vs $10 /$ $156,6.4 \%, p=0.012)$. Among the 469 study patients, 154 (32.8\%) had lung adenocarcinomas that were negative for all oncogenic driver mutations evaluated in the current study.

\section{Discussion}

This study presents for the first time data on the $E G F R$, KRAS, ALK, ROS1, RET, BRAF, ERBB2, MET and PIK3CA mutation frequencies in a representative Swiss cohort of patients with stage I-IV lung adenocarcinoma using NGS as testing method in the majority of patients. Molecular testing was performed in all patients at the time of initial diagnosis during a 4-year period at a primary referral center for lung diseases in Northeastern Switzerland. We also comprehensively studied types of mutations and associations of mutational status with demographic and clinicopathological patient characteristics.

The reported EGFR mutation rate in patients with lung adenocarcinoma varies widely between different populations worldwide, ranging from 10 to 20\% in European and North American cohorts [5, 6, 13-23] to more than $50 \%$ in Asian populations [24, 25]. The wide range of reported EGFR mutation rates among European cohorts might be explained by differences between the published studies with respect to patient selection criteria and methods used for molecular analysis. In a French study by Vallee et al. [19], one of the largest single center studies in Europe, EGFR mutations were detected in $13.5 \%$ of patients with NSCLC and in $14.7 \%$ of patients with lung adenocarcinomas. The authors used allele-specific PCR for evaluation of L858R point mutation and DNA fragment analysis to detect exon 19 deletions. Because other EGFR mutations were not evaluated, the true prevalence of EGFR mutations in this study remains unknown. The INSIGHT study, a large multicenter study comprising 1785 NSCLC patients (including 1393 patients with lung adenocarcinoma), showed an EGFR mutation frequency of $13.8 \%$ in NSCLC patients and of $15.4 \%$ in patients with lung adenocarcinoma [14]. The study analyzed tumor samples from 14 cancer centers in six Central European countries, each with different patient inclusion criteria and testing methods, which makes comparison with other studies more difficult. In addition, mutation testing was not performed at a fixed time point, which could induce bias as mutations may arise during the disease course [23]. Our study results show a prevalence of EGFR mutations that is similar to that reported by Moiseyenko et al. [20] (19.8\%) in a Russian cohort and by Hlinkova et al. [22] (20\%) in a Slovakian cohort, but lower than the EGFR mutation rates reported in two previous studies from Switzerland [5, 6]. Ess et al. [5] retrospectively analyzed population based data on the 
Table 8 Associations between clinicopathological features and ALK rearrangement

\begin{tabular}{|c|c|c|c|}
\hline Variable & $\begin{array}{l}\text { ALK neg. } \\
(n=348)\end{array}$ & $\begin{array}{l}\text { ALK pos. } \\
(n=28)\end{array}$ & $p$-value \\
\hline Age (years) & $64.4 \pm 11.2$ & $61.7 \pm 14.1$ & 0.229 \\
\hline Gender & & & 0.920 \\
\hline Male & $183(52.6)$ & $15(53.6)$ & \\
\hline Female & $165(47.4)$ & $13(46.4)$ & \\
\hline \multicolumn{4}{|l|}{ Smoking status } \\
\hline Never smokers & $72(20.7)$ & $12(42.9)$ & 0.007 \\
\hline Ex-smokers & $124(35.6)$ & $9(32.1)$ & 0.710 \\
\hline Current smokers & $152(43.7)$ & $7(25.0)$ & 0.054 \\
\hline \multicolumn{4}{|l|}{ Clinical stage } \\
\hline । & $22(6.3)$ & $2(7.1)$ & 0.697 \\
\hline$\|$ & $29(8.3)$ & $2(7.1)$ & 0.822 \\
\hline III & $67(19.3)$ & $10(35.7)$ & 0.038 \\
\hline IV & $230(66.1)$ & $14(50.0)$ & 0.086 \\
\hline \multicolumn{4}{|l|}{ T stage } \\
\hline $\mathrm{T} 1$ & $47(13.5)$ & $6(21.4)$ & 0.258 \\
\hline T1a & $8(2.3)$ & $0(0.0)$ & 0.263 \\
\hline$T 1 b$ & $19(5.5)$ & $5(17.9)$ & 0.025 \\
\hline T1c & $20(5.7)$ & $1(3.6)$ & 0.608 \\
\hline $\mathrm{T} 2$ & $88(25.3)$ & $7(25.0)$ & 0.973 \\
\hline T2a & $59(17.0)$ & $4(14.3)$ & 0.711 \\
\hline $\mathrm{T} 2 \mathrm{~b}$ & $29(8.3)$ & $3(10.7)$ & 0.721 \\
\hline T3 & $70(20.1)$ & $4(14.3)$ & 0.455 \\
\hline T4 & $143(41.1)$ & $11(39.3)$ & 0.852 \\
\hline LN metastasis/-es & $259(74.4)$ & $24(85.7)$ & 0.183 \\
\hline \multicolumn{4}{|l|}{ N stage } \\
\hline NO & 89 (25.6) & $4(14.3)$ & 0.183 \\
\hline N1 & $50(14.4)$ & $1(3.6)$ & 0.151 \\
\hline N2 & $93(26.7)$ & $15(53.6)$ & 0.003 \\
\hline N3 & $116(33.3)$ & $8(28.6)$ & 0.606 \\
\hline $\begin{array}{l}\text { Extrathoracic } \\
\text { metastasis/-es }\end{array}$ & $161(46.3)$ & $7(25.0)$ & 0.029 \\
\hline \multicolumn{4}{|l|}{ M stage } \\
\hline Mo & $116(33.3)$ & $14(50.0)$ & 0.074 \\
\hline M1a & $71(20.4)$ & $7(25.0)$ & 0.564 \\
\hline $\mathrm{M} 1 \mathrm{~b}$ & $56(16.1)$ & $0(0.0)$ & 0.013 \\
\hline M1c & $105(30.2)$ & $7(25.0)$ & 0.565 \\
\hline \multicolumn{4}{|l|}{ Localization } \\
\hline Right upper lobe & 96 (27.6) & $0(0.0)$ & 0.001 \\
\hline Right lower lobe & $51(14.7)$ & $5(17.9)$ & 0.587 \\
\hline Middle lobe & $11(3.2)$ & $4(14.3)$ & 0.019 \\
\hline Left upper lobe & 66 (19.0) & $6(21.4)$ & 0.750 \\
\hline Left lower lobe & $43(12.4)$ & $6(21.4)$ & 0.236 \\
\hline Lingula & $11(3.2)$ & $1(3.6)$ & 0.611 \\
\hline
\end{tabular}

Table 8 Associations between clinicopathological features and ALK rearrangement (Continued)

\begin{tabular}{|c|c|c|c|}
\hline Variable & $\begin{array}{l}\text { ALK neg. } \\
(n=348)\end{array}$ & $\begin{array}{l}\text { ALK pos. } \\
(n=28)\end{array}$ & $p$-value \\
\hline Involvement of two lobes & $70(20.1)$ & $6(21.4)$ & 0.868 \\
\hline \multicolumn{4}{|l|}{ Distribution } \\
\hline Central & $70(20.1)$ & $8(28.6)$ & 0.288 \\
\hline Peripheral & $244(70.1)$ & $16(57.1)$ & 0.153 \\
\hline Central and peripheral & $34(9.8)$ & $4(14.3)$ & 0.508 \\
\hline Size (mm) & $44.5 \pm 24.4$ & $46.0 \pm 31.7$ & 0.761 \\
\hline
\end{tabular}

Data are mean values \pm standard deviations for continuous variables and number of patients with percentages in parentheses for categorical variables Bold numbers indicate significant $p$-values $(<0.05)$

frequency of molecular testing, factors affecting testing and the prevalence of EGFR mutations and ALK rearrangements in patients with stage IV or relapsed non-squamous NSCLC (including adenocarcinoma, large cell carcinoma and NOS histology) from 2008 to 2014. Using direct sequencing (EGFR exons 18-21) for EGFR mutation analysis and FISH with a break-apart probe for $A L K$ rearrangement testing, EGFR mutations (exclusively exon 19 deletions and exon 21 L858R mutations!) were detected in $11 \%$ of patients with advanced non-squamous NSCLC and in 13\% of patients with lung adenocarcinoma, while $12 \%$ of patients with non-squamous NSCLC and $10 \%$ of patients with lung adenocarcinoma harbored $A L K$ rearrangements. Other oncogenic driver mutations or associations between EGFR mutation/ALK rearrangement status and clinicopathological characteristics of patients with lung adenocarcinoma were not evaluated. More recently, Schwegler et al. [6] prospectively analyzed population based epidemiological data on overall survival of patients with mutated stage IV lung adenocarcinoma, mostly residents in rural areas of Central Switzerland, from 2010 to 2014. EGFR mutations were detected with Sanger sequencing in $14 \%$ of the patients, while $K R A S$, ERBB2, BRAF and MET mutations and $A L K$ and RET translocations were found in $20 \%, 2 \%, 1 \%, 0.5 \%, 6 \%$ and $0.5 \%$, respectively [6]. In contrast to our study, the types of mutations were not analyzed, and mutational status was not correlated with demographic or clinicopathological features. Possible reasons for the reported lower EGFR mutation rates compared with that of our study may be different modes of patient selection (selection from the molecular database of University Hospital Zurich vs selection from cancer registries), different patient selection criteria (patients with stage I-IV lung adenocarcinoma vs patients with stage IV or relapsed non-squamous NSCLC [5] and patients with stage IV lung adenocarcinoma [6]) and different methods used for mutational analysis (NGS and Sanger sequencing vs Sanger sequencing alone). In contrast to the studies by Ess et al. [5] and Schwegler et al. [6], the majority of patients in our study underwent 
Table 9 Logistic regression analysis of ALK rearrangement

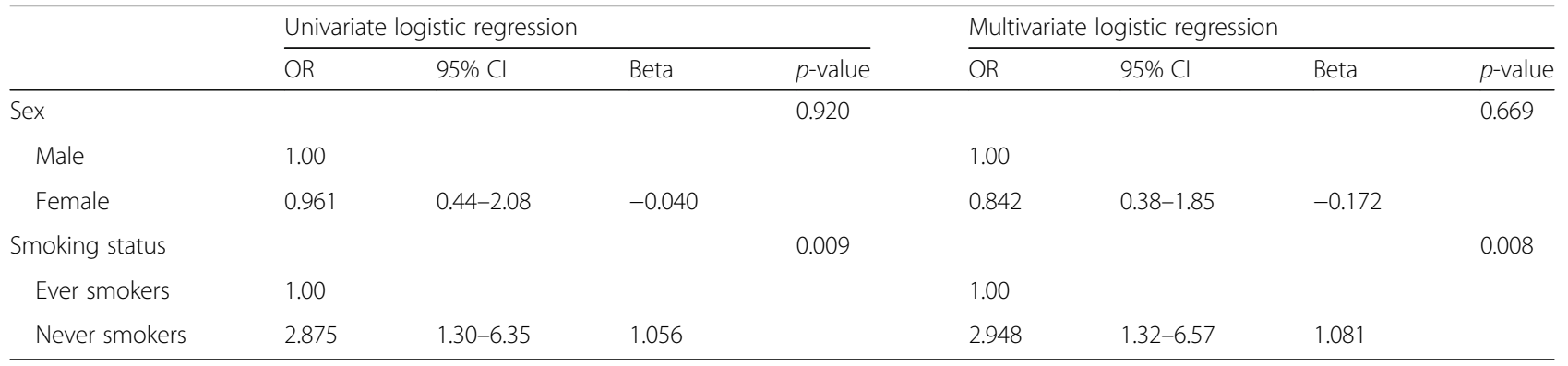

molecular testing with NGS, which has been shown to demonstrate high analytic sensitivity, accurate detection of complex indel mutations, and broad reportable ranges with simultaneous detection of doublet EGFR mutations and concomitant KRAS and BRAF mutations in the clinical diagnostic setting $[2,26]$. In addition, in the study by Schwegler et al. [6] patients with stage I-III lung adenocarcinoma were excluded from the analysis, and $20 \%$ of stage IV lung cancer patients were not tested for oncogenic driver mutations, while in the study by Ess et al. [5] 38\% of patients did not receive molecular analysis. Although we did not assess mutation testing rates at our institution, it can be assumed that the molecular testing rates in the period from 2014 to 2018 were higher than those of previous years and that patients treated at an institution active in clinical research are more regularly tested for predictive biomarkers than patients treated at an institution not participating in clinical research [5]. In accordance with published literature [13-16, 23], we found a significant association of EGFR mutation status with female gender and never smoking status. When we restricted the analysis to female never smokers, we achieved a high EGFR mutation rate of $65.7 \%$ (46/70), a finding consistent with previous reports $[13,24,25]$.

Table 10 Frequency of oncogenic driver mutation in our study cohort

\begin{tabular}{lll}
\hline & $\begin{array}{l}\text { Study population } \\
(\mathrm{n}=469)\end{array}$ & Patients tested $^{a}$ \\
\hline EGFR & $90 / 469(19.2)$ & $90 / 469(19.2)$ \\
KRAS & $159 / 469(33.9)$ & $159 / 443(35.9)$ \\
ALK & $28 / 469(6.0)$ & $28 / 376(7.4)$ \\
BRAF & $12 / 469(2.6)$ & $12 / 309(3.9)$ \\
ERBB2 & $9 / 469(1.9)$ & $9 / 286(3.1)$ \\
MET & $9 / 469(1.9)$ & $9 / 234(3.8)$ \\
PIK3CA & $7 / 469(1.5)$ & $7 / 163(4.3)$ \\
RET & $4 / 469(0.8)$ & $4 / 208(1.9)$ \\
ROS1 & $8 / 469(1.7)$ & $8 / 248(3.2)$ \\
\hline
\end{tabular}

Data are absolute number of patients with percentages in parentheses

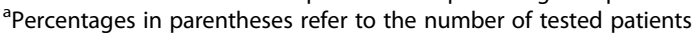

KRAS mutation is one of the most frequent mutations in NSCLC, at least in Caucasian populations, with reported frequencies reaching up to $30 \%$ of lung adenocarcinomas $[13,23,27,28]$, while its prevalence in Asian populations is approximately 10\% [29-31]. KRAS mutations are predominantly found in smokers [32], but they may occur in up to $15 \%$ of non-smokers [27]. To date, no effective anti-KRAS agent has been released, although a number of preclinical studies and clinical trials are currently underway, exploring novel therapeutic approaches to target KRAS mutated NSCLC [33-36]. The KRAS mutation rate in our study was slightly higher than was previously reported for Caucasian populations (which might be related to different smoking habits in this Swiss cohort), but was almost identical to the KRAS mutation rate reported by Brcic et al. [13] in a Croatian cohort. The presence of KRAS mutation in our study was significantly associated with a history of smoking on both univariate and multivariate analyses, while the association of KRAS mutation with gender was statistically significant only on multivariate analysis after adjusting for smoking. This finding adds to a mixed body of literature. Some studies have shown increased incidence of KRAS mutations among females [23], while others found equal frequencies in both men and women [13, 37, 38].

ALK rearrangements are detected in 3-7\% of NSCLC [39-44]. They predominantly occur in non-smokers, lung adenocarcinomas and non-Asian vs Asian populations, while men and women seem to be equally affected [3]. The frequency of $A L K$ rearrangement in our study is consistent with previous reports, as is the association with smoking status (higher frequency in never smokers). Interestingly, our study showed a higher frequency of ipsilateral mediastinal or subcarinal lymph node metastasis (N2) in

Table 11 BRAF mutations in 12 lung cancers

\begin{tabular}{lllll}
\hline & cDNA change & Amino acid change & Frequency & Percentage \\
\hline Exon 15 & c.1799 T > A & p.V600E & 9 & 75.0 \\
Exon 15 & c.1781A > G & p.D594G & 1 & 8.3 \\
Exon 11 & c.1406G > T & p.G469V & 1 & 8.3 \\
Exon 11 & c.1406G > C & p.G469A & 1 & 8.3 \\
\hline
\end{tabular}


Table 12 ERBB2 mutations in 9 lung cancers

\begin{tabular}{|c|c|c|c|c|}
\hline ERBB2 mutation type & Mutation & $\begin{array}{l}\text { Alternate nomenclature } \\
\text { (based on HGVS guidelines) }\end{array}$ & Frequency & Percentage \\
\hline Exon 20 insertion & $\begin{array}{l}\text { p.A775_G776ins } Y V M A \\
\text { (c.2324_2325ins12) }\end{array}$ & $\begin{array}{l}\text { p.Y772_A775dup } \\
\text { (c.2313_2324dup) }\end{array}$ & 5 & 55.6 \\
\hline Exon 20 insertion & $\begin{array}{l}\text { p.P780_Y781insGSP } \\
\text { (c.2339_2340insGGCTCCCCA) }\end{array}$ & $\begin{array}{l}\text { p.G778_P780dup } \\
\text { (c.2331_2339dup) }\end{array}$ & 1 & 11.1 \\
\hline Exon 20 insertion & $\begin{array}{l}\text { p.G776>VC } \\
\text { (c.2326_2327insTGT) }\end{array}$ & $\begin{array}{l}\text { p.G776delinsVC } \\
\text { (c.2326_2327insTGT) }\end{array}$ & 1 & 11.1 \\
\hline Exon 8 missense mutation & $\begin{array}{l}\text { p.Q527* } \\
\text { (c.1579C > T) }\end{array}$ & $\begin{array}{l}\text { p.Gln527Ter } \\
\text { (c.1579C > T) }\end{array}$ & 1 & 11.1 \\
\hline Exon 13 nonsense mutation & $\begin{array}{l}\text { p.S310Tyr } \\
(c .929 \text { C > A) }\end{array}$ & $\begin{array}{l}\text { p.Ser310Tyr } \\
\text { (c.929C > A) }\end{array}$ & 1 & 11.1 \\
\hline
\end{tabular}

HGVS Human Genome Variation Society

$A L K$-rearranged tumors compared with non-rearranged, EGFR mutated and KRAS mutated tumors, while no significant differences were found between $A L K$-rearranged and non-rearranged/EGFR mutated/KRAS mutated tumors with regard to N0, N1 and N3 stages. In addition, $A L K$ rearranged lung adenocarcinomas were more frequently pT1 tumors compared with $A L K$-non rearranged lung cancer. In a previous study, evaluating surgically resected stage I-III NSCLCs, Paik et al. [45] found that ALK FISH-positive NSCLC cases showed lower tumor stage (pT1), but had more frequently lymph node metastases compared with $A L K$ FISH-negative NSCLC cases. The authors suggested that $A L K$-rearranged lung cancer might have unique biological features with a tendency to early lymph node metastasis despite the small primary tumor size, which could explain higher incidences of $A L K$ rearrangement in advanced NSCLC compared with surgically resectable lung cancer [45].

The frequency of $B R A F$ mutations in the current study seems to be among the higher previously reported mutation rates [46-48], but is still lower than the mutation rate reported by Illei et al. [26] (6.3\%), who analyzed 1006 lung cancers with NGS. Other targetable genomic alterations in NSCLC, including RET and ROS1 rearrangements and ERBB2, MET exon 14 skipping and PIK3CA mutations, are present only in a small percentage of NSCLC patients ( 1-2\% [49], 2\% [50], 2-4\% [51-53], 3-4\% [54-57] and $2-5 \%[26,58,59]$, respectively). While our study with a limited sample size of $R E T$ and $R O S 1$ rearranged lung cancer showed no significant differences between RET or ROS1 rearranged and non-rearranged tumors regarding clinicopathological characteristics, previous investigations have reported a higher incidence of RET and ROS1 rearrangements in younger age group and never smokers $[60$, 61] as well as a significant association of RET rearranged NSCLC with small primary tumor size and lymph node involvement [60, 62]. According to previous reports [63], ERBB2 mutations in NSCLC are more common in females, Asian cohorts and never-smokers. While our study showed no significant association of ERBB2 mutation with female gender, we could confirm the higher prevalence of $E R B B 2$ mutations in never smoking patients. PIK3CA mutations are more commonly encountered in squamous NSCLC $[58,59,64]$ and seem to confer inferior prognosis in lung adenocarcinoma [65]. Interestingly, PIK3CA mutations have been reported to occur in parallel with other oncogenic driver mutations [66, 67], as was the case in 5 of 7 PIK3CA mutated tumors in the present study. Regarding the clinicopathological characteristics of $M E T$ exon 14 skipping mutation-positive tumors, three retrospective studies showed that $M E T$ exon 14 skipping positivity in NSCLC patients is significantly associated with advanced age [68-70]. In the current study, we found no significant difference in mean age between patients with and those without $M E T$ exon 14 mutated tumors. However, we acknowledge that the sample size of $M E T$ exon 14 mutated tumors was too small to draw meaningful conclusions.

\section{Conclusion}

Our study presents data on the frequency of oncogenic driver mutations in a Northeastern Swiss population with stage I-IV lung adenocarcinoma using NGS as testing method in the majority of cases. A number of studies already analyzed oncogenic driver mutation frequencies, notably EGFR, KRAS and $A L K$ mutation rates, in different populations from European countries. However, based on the available data, the true prevalence of mutations in lung adenocarcinoma is often difficult to determine due to patient selection bias, different testing platforms used for analysis and the histological heterogeneity of tumors included in the studies. Although we cannot exclude some selection toward patients with higher likelihood of mutated tumors in the current study, a major selection bias is unlikely to have occurred because the epidemiological characteristics of our study population are similar to those of the INSIGHT study and other previous investigations. We found a relatively high EGFR mutation rate, while KRAS, BRAF, ERBB2, MET and PIK3CA mutation and $A L K, R E T$ and ROS1 rearrangement frequencies were 
similar to those of previous reports. EGFR and KRAS mutation was significantly associated with gender and smoking status, while $A L K$ rearrangement was significantly associated with smoking status alone.

\section{Additional file}

Additional file 1: Table S1. Doublet EGFR mutations in 90 lung cancers. Table S2. Comparison of EGFR and KRAS mutated tumors. Table S3. Comparison of EGFR mutated and ALK rearranged tumors. Table $\mathbf{S 4}$. Comparison of KRAS mutated and ALK rearranged tumors. (DOCX $30 \mathrm{~kb}$ )

\section{Abbreviations}

ALK: Anaplastic lymphoma kinase; BRAF: B rapidly accelerated fibrosarcoma; EGFR: Epidermal growth factor receptor; ERBB2: Erb-b2 tyrosine kinase 2; FISH: Fluorescence in situ hybridization; HGVS: Human Genome Variation Society; ICC: Immunocytochemistry; IHC: Immunohistochemistry; KRAS: Kirsten rat sarcoma; MET: Mesenchymal epithelial transition protooncogene; NGS: Next generation sequencing; NSCLC: Non-small cell lung cancer; PCR: Polymerase chain reaction; PIK3CA: Phosphatidylinositol-3 kinase catalytic subunit alpha; RET: Rearranged during transfection proto-oncogene; ROS1: ROS proto-oncogene 1; TKI: Tyrosine kinase inhibitor

\section{Acknowledgements}

The authors would like to thank Prof. Dieter Zimmermann from the Institute of Pathology and Molecular Pathology, University Hospital Zurich, for providing information about molecular analyses.

\section{Funding}

The authors received no specific funding for this work.

\section{Availability of data and materials}

The datasets supporting the conclusions of this article are available from the corresponding author on reasonable request.

\section{Authors' contributions}

AS was responsible for the conceptualization of this study and the project administration. AG, CG and MR were responsible for data collection and literature analysis. AG and CG were responsible for analysis and data interpretation. AG wrote the manuscript. All authors critically revised the manuscript and approved the final version.

\section{Ethics approval and consent to participate}

The study was approved by the Cantonal Ethics Committee of Zurich (StVNo. 2009/14-0029). Formal patient consent was not required because of the retrospective study design.

\section{Consent for publication \\ Not applicable}

\section{Competing interests}

The authors declare that they have no competing interests.

\section{Publisher's Note}

Springer Nature remains neutral with regard to jurisdictional claims in published maps and institutional affiliations.

\section{Author details}

'Institute of Pathology and Molecular Pathology, Clinical Pathology, University Hospital Zurich, Rämistrasse 100, 8091 Zurich, Switzerland. ${ }^{2}$ Institute of Pathology, Kepler University Hospital, Krankenhausstraße 9, 4021 Linz, Austria. ${ }^{3}$ Institute of Pathology and Molecular Pathology, Diagnostic Molecular Pathology, University Hospital Zurich, Rämistrasse 100, 8091 Zurich, Switzerland
Received: 13 November 2018 Accepted: 1 February 2019

Published online: 11 February 2019

\section{References}

1. Bray F, Ferlay J, Soerjomataram I, Siegel RL, Torre LA, Jemal A. Global cancer statistics 2018: GLOBOCAN estimates of incidence and mortality worldwide for 36 cancers in 185 countries. CA Cancer J Clin. 2018;68:394-424. https:// doi.org/10.3322/caac.21492.

2. Jing C, Mao X, Wang Z, Sun K, Ma R, Wu J, et al. Next-generation sequencing-based detection of EGFR, KRAS, BRAF, NRAS, PIK3CA, Her-2 and TP53 mutations in patients with non-small cell lung cancer. Mol Med Rep. 2018;18:2191-7. https://doi.org/10.3892/mmr.2018.9210.

3. Zhao F, Xu M, Lei H, Zhou Z, Wang L, Li P, et al. Clinicopathological characteristics of patients with non-small-cell lung cancer who harbor EML4-ALK fusion gene: a meta-analysis. PLoS One. 2015;10:e0117333. https://doi.org/10.1371/journal.pone.0117333.

4. Gkolfinopoulos S, Mountzios G. Beyond EGFR and ALK: targeting rare mutations in advanced non-small cell lung cancer. Ann Transl Med. 2018;6: 142. https://doi.org/10.21037/atm.2018.04.28.

5. Ess SM, Herrmann C, Frick H, Krapf M, Cerny T, Jochum W, et al. Epidermal growth factor receptor and anaplastic lymphoma kinase testing and mutation prevalence in patients with advanced non-small cell lung cancer in Switzerland: a comprehensive evaluation of real world practices. Eur J Cancer Care. 2017;26:e12721. https://doi.org/10.1111/ecc.12721.

6. Schwegler C, Kaufmann D, Pfeiffer D, Aebi S, Diebold J, Gautschi O. Population-level effect of molecular testing and targeted therapy in patients with advanced pulmonary adenocarcinoma: a prospective cohort study. Virchows Arch. 2018;472:581-8. https://doi.org/10.1007/s00428-017-2268-y.

7. Arndt V, Feller A, Hauri D, Heusser R, Junker C, Kuehni C, Lorez M, Pfeiffer V, Roy E, Schindler M. Swiss cancer report 2015. Neuchatel: Federal Statistical Office; 2016

8. Oberli LS, Valeri F, Korol D, Rohrmann S, Dehler $\mathrm{S} .31$ years of lung cancer in the canton of Zurich, Switzerland: incidence trends by sex, histology and laterality. Swiss Med Wkly. 2016;146:w14327. https://doi.org/10.4414/smw. 2016.14327.

9. Lorez M, Rohrmann S, Heusser R, Volker A, NICER Working Group. Lung cancer trends by histologic subtype in Switzerland: Schweizer Krebsbulletin. 2017;37:179-85.

10. Brierley JD, Gospodarowicz MK, Wittekind C, editors. TNM classification of malignant tumours. UK: John Wiley \& Sons, Ltd; 2017.

11. Velizheva NP, Rechsteiner MP, Valtcheva N, Freiberger SN, Wong CE, Vrugt B, et al. Targeted next-generation-sequencing for reliable detection of targetable rearrangements in lung adenocarcinoma - a single center retrospective study. Pathol Res Pract. 2018;214:572-8. https://doi.org/10. 1016/j.prp.2018.02.001.

12. Velizheva NP, Rechsteiner MP, Wong CE, Zhong Q, Rössle M, Bode B, et al. Cytology smears as excellent starting material for next-generation sequencing-based molecular testing of patients with adenocarcinoma of the lung. Cancer Cytopathol. 2017;125:30-40. https://doi.org/10.1002/ cncy.21771.

13. Brcic L, Jakopovic M, Misic M, Seiwerth F, Kern I, Smojver-Jezek S, et al. Analysis of the frequency of EGFR, KRAS and ALK mutations in patients with lung adenocarcinoma in Croatia. Diagn Pathol. 2016;11:90. https://doi.org/ 10.1186/s13000-016-0544-9.

14. Ramlau R, Cufer T, Berzinec P, Dziadziuszko R, Olszewski W, Popper H, et al. Epidermal growth factor receptor mutation-positive non-small-cell lung cancer in the real-world setting in Central Europe: the INSIGHT study. J Thorac Oncol. 2015;10:1370-4. https://doi.org/10.1097/JTO. 0000000000000621

15. Milella M, Nuzzo C, Bria E, Sperduti I, Visca P, Buttitta F, et al. EGFR molecular profiling in advanced NSCLC: a prospective phase II study in molecularly/ clinically selected patients pretreated with chemotherapy. J Thorac Oncol. 2012;7:672-80. https://doi.org/10.1097/JTO.0b013e31824a8bde.

16. Zaric B, Stojsic V, Kovacevic T, Sarcev T, Tepavac A, Jankovic R, et al. Clinical characteristics, tumor, node, metastasis status, and mutation rate in domain of epidermal growth factor receptor gene in serbian patients with lung adenocarcinoma. J Thorac Oncol. 2014;9:1406-10. https://doi.org/10.1097/ JTO.0000000000000242.

17. Helland Å, Skaug HM, Kleinberg L, Iversen ML, Rud AK, Fleischer T, et al. EGFR gene alterations in a Norwegian cohort of lung cancer patients 
selected for surgery. J Thorac Oncol. 2011;6:947-50. https://doi.org/10.1097/ JTO.0b013e31820db209.

18. Berg J, Fjellbirkeland L, Suhrke $P$, Jebsen $P$, Lund-Iversen $M$, Kleinberg $L$, et al. EGFR mutation testing of lung cancer patients - experiences from Vestfold hospital trust. Acta Oncol. 2016;55:149-55. https://doi.org/10 3109/0284186X.2015.1062537.

19. Vallee A, Sagan C, Le Loupp AG, Bach K, Dejoie T, Denis MG. Detection of EGFR gene mutations in non-small cell lung cancer: lessons from a single-institution routine analysis of 1,403 tumor samples. Int J Oncol. 2013:43:1045-51. https://doi.org/10.3892/ijo.2013.2056.

20. Moiseyenko VM, Procenko SA, Levchenko EV, Barchuk AS, Moiseyenko FV, lyevleva AG, et al. High efficacy of first-line gefitinib in non-Asian patients with EGFR-mutated lung adenocarcinoma. Onkologie. 2010;33:231-8. https://doi.org/10.1159/000302729.

21. Midha A, Dearden S, McCormack R. EGFR mutation incidence in non-smallcell lung cancer of adenocarcinoma histology: a systematic review and global map by ethnicity (mutMapll). Am J Cancer Res. 2015;5:2892-911.

22. Hlinkova K, Babal P, Berzinec P, Majer I, Mikle-Barathova Z, Piackova B, et al. Evaluation of 2-year experience with EGFR mutation analysis of small diagnostic samples. Diagn Mol Pathol. 2013;22:70-5. https://doi.org/10.1097/ PDM.0b013e31827e6984

23. Bauml J, Mick R, Zhang $Y$, Watt CD, Vachani A, Aggarwal $C$, et al. Frequency of EGFR and KRAS mutations in patients with non small cell lung cancer by racial background: do disparities exist? Lung Cancer. 2013;81:347-53. https:// doi.org/10.1016/j.lungcan.2013.05.011.

24. Xia N, An J, Jiang QQ, Li M, Tan J, Hu CP. Analysis of EGFR, EML4-ALK, KRAS, and C-MET mutations in Chinese lung adenocarcinoma patients. Exp Lung Res. 2013;39:328-35. https://doi.org/10.3109/01902148.2013.819535.

25. Gao B, Sun Y, Zhang J, Ren Y, Fang R, Han X, et al. Spectrum of LKB1, EGFR, and KRAS mutations in chinese lung adenocarcinomas. J Thorac Oncol. 2010;5:1130-5. https://doi.org/10.1097/JTO.0b013e3181e05016.

26. Illei PB, Belchis D, Tseng LH, Nguyen D, De Marchi F, Haley L, et al. Clinical mutational profiling of 1006 lung cancers by next generation sequencing. Oncotarget. 2017:8:96684-96. https://doi.org/10.18632/oncotarget.18042.

27. Riely GJ, Kris MG, Rosenbaum D, Marks J, Li A, Chitale DA, et al. Frequency and distinctive spectrum of KRAS mutations in never smokers with lung adenocarcinoma. Clin Cancer Res. 2008;14:5731-4. https://doi.org/10.1158/ 1078-0432.CCR-08-0646.

28. Dogan S, Shen R, Ang DC, Johnson ML, D'Angelo SP, Paik PK, et al. Molecular epidemiology of EGFR and KRAS mutations in 3,026 lung adenocarcinomas: higher susceptibility of women to smoking-related KRASmutant cancers. Clin Cancer Res. 2012;18:6169-77. https://doi.org/10.1158/ 1078-0432.CCR-11-3265.

29. Takamochi K, Oh S, Suzuki K. Differences in EGFR and KRAS mutation spectra in lung adenocarcinoma of never and heavy smokers. Oncol Lett. 2013;6:1207-12. https://doi.org/10.3892/ol.2013.1551.

30. Bae NC, Chae MH, Lee MH, Kim KM, Lee EB, Kim CH, et al. EGFR, ERBB2, and KRAS mutations in Korean non-small cell lung cancer patients. Cancer Genet Cytogenet. 2007;173:107-13. https://doi.org/10.1016/j.cancergencyto. 2006.10.007.

31. Liu L, Liu J, Shao D, Deng Q, Tang H, Liu Z, et al. Comprehensive genomic profiling of lung cancer using a validated panel to explore therapeutic targets in east Asian patients. Cancer Sci. 2017;108:2487-94. https://doi.org/ 10.1111/cas.13410.

32. Ahrendt SA, Decker PA, Alawi EA, Zhu Yr YR, Sanchez-Cespedes M, Yang SC, et al. Cigarette smoking is strongly associated with mutation of the K-ras gene in patients with primary adenocarcinoma of the lung. Cancer. 2001;92: $1525-30$.

33. Ferrer I, Zugazagoitia J, Herbertz S, John W, Paz-Ares L, Schmid-Bindert G. KRAS-mutant non-small cell lung cancer: from biology to therapy. Lung Cancer. 2018;124:53-64. https://doi.org/10.1016/.lungcan.2018.07.013.

34. Wood K, Hensing T, Malik R, Salgia R. Prognostic and predictive value in KRAS in non-small-cell lung cancer: a review. JAMA Oncol. 2016;2:805-12. https://doi.org/10.1001/jamaoncol.2016.0405.

35. Jänne PA, Shaw AT, Pereira JR, Jeannin G, Vansteenkiste J, Barrios $C$, et al. Selumetinib plus docetaxel for KRAS-mutant advanced non-small-cell lung cancer: a randomised, multicentre, placebo-controlled, phase 2 study. Lancet Oncol. 2013;14:38-47. https://doi.org/10.1016/S1470-2045(12)70489-8.

36. A Study of Abemaciclib (LY2835219) in participants with previously treated KRAS mutated lung cancer (JUNIPER). Avalaible online: https://clinicaltrials. gov/ct2/show/NCT02152631. Accessed 10 Nov 2018.
37. Bacchi CE, Ciol H, Queiroga EM, Benine LC, Silva LH, Ojopi EB. Epidermal growth factor receptor and KRAS mutations in Brazilian lung cancer patients. Clinics (Sao Paulo). 2012;67:419-24. https://doi.org/papers2:// publication/uuid/F04AA1B0-F128-493A-A47B-F45F7553371A

38. Rouquette I, Lauwers-Cances V, Allera C, Brouchet L, Milia J, Nicaise Y, et al. Characteristics of lung cancer in women: importance of hormonal and growth factors. Lung Cancer. 2012;76:280-5. https://doi.org/10.1016/j. lungcan.2011.11.023.

39. Kwak EL, Bang YJ, Camidge DR, Shaw AT, Solomon B, Maki RG, et al. Anaplastic lymphoma kinase inhibition in non-small-cell lung cancer. N Engl J Med. 2010;363:1693-703. https://doi.org/10.1056/NEJMoa1006448.

40. Takeuchi K, Choi YL, Soda M, Inamura K, Togashi Y, Hatano S, et al. Multiplex reverse transcription-PCR screening for EML4-ALK fusion transcripts. Clin Cancer Res. 2008;14:6618-24. https://doi.org/10.1158/ 1078-0432.CCR-08-1018.

41. Wong DW, Leung EL, So KK, Tam IY, Sihoe AD, Cheng LC, et al. The EML4ALK fusion gene is involved in various histologic types of lung cancers from nonsmokers with wild-type EGFR and KRAS. Cancer. 2009;115:1723-33. https://doi.org/10.1002/cncr.24181.

42. Soda M, Choi YL, Enomoto M, Takada S, Yamashita Y, Ishikawa S, et al. Identification of the transforming EML4-ALK fusion gene in non-small-cell lung cancer. Nature. 2007;448:561-6. https://doi.org/10.1038/nature05945.

43. Shinmura K, Kageyama S, Tao H, Bunai T, Suzuki M, Kamo T, et al. EML4-ALK fusion transcripts, but no NPM-, TPM3-, CLTC-, ATIC-, or TFG-ALK fusion transcripts, in non-small cell lung carcinomas. Lung Cancer. 2008;61:163-9. https://doi.org/10.1016/j.lungcan.2007.12.013.

44. Koivunen JP, Mermel C, Zejnullahu K, Murphy C, Lifshits E, Holmes AJ, et al. EML4-ALK fusion gene and efficacy of an ALK kinase inhibitor in lung cancer. Clin Cancer Res. 2008;14:4275-83. https://doi.org/10.1158/1078-0432. CCR-08-0168.

45. Paik JH, Choi CM, Kim H, Jang SJ, Choe G, Kim DK, et al. Clinicopathologic implication of ALK rearrangement in surgically resected lung cancer: a proposal of diagnostic algorithm for ALK-rearranged adenocarcinoma. Lung Cancer. 2012;76:403-9. https://doi.org/10.1016/j.lungcan.2011.11.008.

46. Pratilas CA, Hanrahan AJ, Halilovic E, Persaud Y, Soh J, Chitale D, et al. Genetic predictors of MEK dependence in non-small cell lung cancer. Cancer Res. 2008; 68:9375-83. https:/doi.org/10.1158/0008-5472.CAN-08-2223.

47. Cardarella S, Ogino A, Nishino M, Butaney M, Shen J, Lydon C, et al. Clinical, pathologic, and biologic features associated with BRAF mutations in nonsmall cell lung cancer. Clin Cancer Res. 2013;19:4532-40. https://doi.org/10. 1158/1078-0432.CCR-13-0657.

48. Paik PK, Arcila ME, Fara M, Sima CS, Miller VA, Kris MG, et al. Clinical characteristics of patients with lung adenocarcinomas harboring BRAF mutations. J Clin Oncol. 2011;29:2046-51. https://doi.org/10.1200/JCO.2010.33.1280.

49. Nikiforov YE. Thyroid carcinoma: molecular pathways and therapeutic targets. Mod Pathol. 2008;21(Suppl 2):S37-43. https://doi.org/10.1038/ modpathol.2008.10.

50. Gainor JF, Shaw AT. Novel targets in non-small cell lung cancer: ROS1 and RET fusions. Oncologist. 2013;18:865-75. https://doi.org/10.1634/ theoncologist.2013-0095.

51. Arcila ME, Chaft JE, Nafa K, Roy-Chowdhuri S, Lau C, Zaidinski M, et al. Prevalence, clinicopathologic associations, and molecular spectrum of ERBB2 (HER2) tyrosine kinase mutations in lung adenocarcinomas. Clin Cancer Res. 2012;18:4910-8. https://doi.org/10.1158/1078-0432.CCR-12-0912.

52. Buttitta F, Barassi F, Fresu G, Felicioni L, Chella A, Paolizzi D, et al. Mutational analysis of the HER2 gene in lung tumors from Caucasian patients: mutations are mainly present in adenocarcinomas with bronchioloalveolar features. Int J Cancer. 2006;119:2586-91. https://doi.org/10.1002/ijc.22143.

53. Shigematsu H, Takahashi T, Nomura M, Majmudar K, Suzuki M, Lee H, et al. Somatic mutations of the HER2 kinase domain in lung adenocarcinomas. Cancer Res. 2005;65:1642-6. https://doi.org/10.1158/0008-5472.CAN-04-4235.

54. Frampton GM, Ali SM, Rosenzweig M, Chmielecki J, Lu X, Bauer TM, et al. Activation of MET via diverse exon 14 splicing alterations occurs in multiple tumor types and confers clinical sensitivity to MET inhibitors. Cancer Discov. 2015;5:850-9. https://doi.org/10.1158/2159-8290.CD-15-0285.

55. Seo JS, Ju YS, Lee WC, Shin JY, Lee JK, Bleazard T, et al. The transcriptional landscape and mutational profile of lung adenocarcinoma. Genome Res. 2012;22:2109-19. https://doi.org/10.1101/gr.145144.112.

56. Cancer Genome Atlas Research Network. Comprehensive molecular profiling of lung adenocarcinoma. Nature. 2014;511:543-50. https://doi.org/ 10.1038/nature13385. 
57. Onozato R, Kosaka T, Kuwano H, Sekido Y, Yatabe Y, Mitsudomi T. Activation of MET by gene amplification or by splice mutations deleting the juxtamembrane domain in primary resected lung cancers. J Thorac Oncol. 2009:4:5-11. https://doi.org/10.1097/JTO.0b013e3181913e0e.

58. Kawano O, Sasaki H, Endo K, Suzuki E, Haneda H, Yukiue H, et al. PIK3CA mutation status in Japanese lung cancer patients. Lung Cancer. 2006;54: 209-15. https://doi.org/10.1016/j.lungcan.2006.07.006.

59. Yamamoto $H$, Shigematsu $H$, Nomura M, Lockwood WW, Sato M, Okumura $\mathrm{N}$, et al. PIK3CA mutations and copy number gains in human lung cancers. Cancer Res. 2008;68:6913-21. https://doi.org/10. 1158/0008-5472.CAN-07-5084

60. Qian Y, Chai S, Liang Z, Wang Y, Zhou Y, Xu X, et al. KIF5B-RET fusion kinase promotes cell growth by multilevel activation of STAT3 in lung cancer. Mol Cancer. 2014;13:176. https://doi.org/10.1186/1476-4598-13-176.

61. Shaw AT, Ou SH, Bang YJ, Camidge DR, Solomon BJ, Salgia R, et al. Crizotinib in ROS1-rearranged non-small-cell lung cancer. N Engl J Med. 2014;371:1963-71. https://doi.org/10.1056/NEJMoa1406766.

62. Wang R, Hu H, Pan Y, Li Y, Ye T, Li C, et al. RET fusions define a unique molecular and clinicopathologic subtype of non-small-cell lung cancer. J Clin Oncol. 2012;30:4352-9. https://doi.org/10.1200/JCO.2012.44.1477.

63. Liu L, Shao X, Gao W, Bai J, Wang R, Huang P, et al. The role of human epidermal growth factor receptor 2 as a prognostic factor in lung cancer: a meta-analysis of published data. J Thorac Oncol. 2010;5:1922-32.

64. Spoerke JM, O'Brien C, Huw L, Koeppen H, Fridlyand J, Brachmann RK, et al. Phosphoinositide 3-kinase (PI3K) pathway alterations are associated with histologic subtypes and are predictive of sensitivity to PI3K inhibitors in lung cancer preclinical models. Clin Cancer Res. 2012;18:6771-83. https:// doi.org/10.1158/1078-0432.CCR-12-2347.

65. Zhang L, Shi L, Zhao X, Wang Y, Yue W. PIK3CA gene mutation associated with poor prognosis of lung adenocarcinoma. Onco Targets Ther. 2013;6: 497-502. https://doi.org/10.2147/OTT.S41643.

66. Chaft JE, Arcila ME, Paik PK, Lau C, Riely GJ, Pietanza MC, et al. Coexistence of PIK3CA and other oncogene mutations in lung adenocarcinoma-rationale for comprehensive mutation profiling. Mol Cancer Ther. 2012;11:485-91. https://doi.org/10.1158/1535-7163.MCT-11-0692.

67. Wang L, Hu H, Pan Y, Wang R, Li Y, Shen L, et al. PIK3CA mutations frequently coexist with EGFR/KRAS mutations in non-small cell lung cancer and suggest poor prognosis in EGFR/KRAS wildtype subgroup. PLoS One. 2014;9:e88291. https://doi.org/10.1371/journal.pone.0088291.

68. Lee GD, Lee SE, Oh DY, Yu DB, Jeong HM, Kim J, et al. MET exon 14 skipping mutations in lung adenocarcinoma: clinicopathologic implications and prognostic values. J Thorac Oncol. 2017;12:1233-46. https://doi.org/10. 1016/j.jtho.2017.04.031.

69. Awad MM, Oxnard GR, Jackman DM, Savukoski DO, Hall D, Shivdasani P, et al. MET exon 14 mutations in non-small-cell lung cancer are associated with advanced age and stage-dependent MET genomic amplification and c-met overexpression. J Clin Oncol. 2016;34:721-30. https://doi.org/10.1200/JCO. 2015.63.4600

70. Zheng D, Wang R, Ye T, Yu S, Hu H, Shen X, et al. MET exon 14 skipping defines a unique molecular class of non-small cell lung cancer. Oncotarget. 2016;7:41691-702. https://doi.org/10.18632/oncotarget.9541.

Ready to submit your research? Choose BMC and benefit from:

- fast, convenient online submission

- thorough peer review by experienced researchers in your field

- rapid publication on acceptance

- support for research data, including large and complex data types

- gold Open Access which fosters wider collaboration and increased citations

- maximum visibility for your research: over $100 \mathrm{M}$ website views per year

At BMC, research is always in progress.

Learn more biomedcentral.com/submissions 